\title{
Validation of device for detection of metallic foreign bodies in cattle
}

\section{Maria Luisa de Andrade Carvalho ${ }^{1}$ (i) Renata Luisa Soares ${ }^{2}$ (i) Hugo Richard Dÿck ${ }^{3}$ Gunther Schartner ${ }^{3}$ Edilson José Vieira ${ }^{3}$ Ricardo Diego Torres ${ }^{4}$ Rüdiger Daniel Ollhoff ${ }^{* *}$ (1)}

${ }^{1}$ Programa de Pós-graduação em Ciência Animal, Pontifícia Universidade Católica do Paraná (PUCPR), Curitiba, PR, Brasil. ${ }^{2}$ Médica veterinária autônoma, Curitiba, PR, Brasil.

${ }^{3}$ Médicos veterinários da Cooperativa Mista Agropecuária de Witmarsum, Curitiba, PR, Brasil. ${ }^{4}$ Programa de Pós-graduação em Engenharia Mecânica, Pontifícia Universidade Católica do Paraná (PUCPR), Curitiba, PR, Brasil. ${ }^{5}$ Programa de Pós-graduação em Ciência Animal, Pontifícia Universidade Católica do Paraná (PUCPR), 80215-901, Curitiba, PR, Brasil. E-mail:daniel.ollhoff@pucpr.br. "Corresponding author.

ABSTRACT: The ingestion of foreign bodies, mainly metallic (MFB-metallic foreign body), by cattle is frequent and can lead to death. For diagnostic purposes, reticular pain tests are routinely used, and ferroscopy is still unusual, even as a diagnostic aid. The objective of this study was to validate the application of the GMS 120 Professional BOSCH ${ }^{\circledR}$ metal detector $(M D)$ in the detection of MFB in the bovine species and describe its use in field cases. Fifty MFBs of varying shape, size, and weight were evaluated with an MD, initially on a flat and inert surface, and then in a permanent rumen fistulated cow. Retrospectively, a database from 2000 to 2017 with 122015 cattle was accessed, of which 31865 were examined after the introduction of MD usage in 2013. Fifteen cows positive for reticular pain tests were prospectively evaluated and eight cows were diagnosed with MFB through MD usage. The mean distance for MFB best detection on the inert surface was $4.6 \mathrm{~cm}$. In the fistulated cow, it was not possible to detect any MFBs, regardless of the size or weight of the material. The MFB detection capacity increased with MD use, which can be considered a diagnostic aid in specific situations. Depending on the body condition of the bovine, false negatives may occur with the use of GMS 120 Professional Bosch ${ }^{\circledR}$ metal detector.

Key words: diagnosis, foreign bodies, metal detector, traumatic reticuloperitonitis.

Validação de aparelho para detecção de corpos estranhos metálicos em bovinos

RESUMO: A ingestão de corpos estranhos, principalmente metálicos (CEM), pelos bovinos é frequente e pode levar à sua morte. Para fins diagnósticos, as provas de dor reticular são usados de forma rotineira, sendo ainda pouco usual a ferroscopia, mesmo como auxílio diagnóstico. Neste trabalho procurou-se validar a aplicação do detector de metais (DM), marca GMS 120 Professional BOSCH ${ }^{\circledR}$ no reconhecimento de CEM na espécie bovina, além de descrever seu uso em casos a campo. CEM ( $n=50)$ de forma, tamanho e peso variados foram selecionados e avaliados com o DM, inicialmente sobre uma superficie plana e inerte e depois in vivo em uma vaca com fistula ruminal. Retrospectivamente, acessou-se um banco de dados dos anos 2000 a 2017 com 122015 bovinos, com 31865 bovinos atendidos após a introdução do DM no ano de 2013. Prospectivamente, avaliaram-se 15 vacas positivas para o teste de dor reticular, oito vacas foram diagnosticadas com CEM através do DM. A distância média para a melhor detecção dos CEM na superficie inerte foi de 4,6 cm. Em vaca fistulada não foi possível detectar nenhum CEM, independentemente do tamanho e peso do material. A campo, após a introdução do uso do DM aumentou a capacidade de detecção dos CEM. O DM pode ser considerado um auxílio diagnóstico em situações específicas. Dependendo da condição corporal do bovino, falsos negativos podem ocorrer com o uso do aparelho GMS 120 Professional Bosch $^{\circledR}$.

Palavras-chave: diagnóstico, corpos estranhos, detector de metal, retículoperitonite-traumática.

\section{INTRODUCTION}

The feed that is supplied to cattle is usually eaten quickly and without interruption, increasing the frequency of foreign body (FB) ingestion (DIRKSEN, 1993). In abattoirs, more than half of the cattle forestomachs examined may contain metallic foreign bodies (MFB) as well as wood and stones (EDDY, 2008). The perforating traumatic injuries caused by MFBs have an economic impact, not only due to the death of the animals, but also due to decreased milk production, feed conversion, and reproductive capacity (Dirksen et al. 2002).

Ingestion of $\mathrm{FB}$ or $\mathrm{MFB}$ is related to neglected farm management, often after a renovation 
or fence maintenance; pieces of wire, nails, and other related items are forgotten in the pens and facilities (GARCIA et al., 1996; EDDY, 2008). The MFB in the pasture can be collected by forage harvesters and accidentally inserted into the cattle feed (EDDY, 2008). Maintenance-free machinery can also be a source of MFB (OLLHOFF \& BIRGEL JR., 2012). The MFB ingestion occurs more often in adult cattle than in younger animals (STÖBER, 1993; PENNY; MAGRAE, 2011).

Ingested MFBs become lodged in the reticulum and MFB penetration and its consequences depend on the object's shape, size, location, and traumatic force (SEREN, 1975). If the object moves in a cranial direction, diaphragm, pericardium, and cardiac muscle perforation may occur, resulting in a reticulum-pericarditis, but only sharp objects, 5 to 10 cm length, penetrate the reticular wall (EDDY, 2008), triggering adhesions between organs and abscess formation (GUARD, 2006; EDDY, 2008).

The clinical symptoms of MFB ingestion and injury vary with disease progression. In cattle with recent MFB penetration, a tympanic sound can be heard between the reticulum and rumen during percussion of the left ventral abdominal wall (DIRKSEN, 1993). The animals may also display pain grunts and maintain antalgic positions, such as positioning the thoracic limbs higher than the pelvic (FEITOSA, 2004). For simple reticuloperitonitis, the signs, when present, are more discrete. Reticuloperitonitis may additionally be associated with anorexia, reduced milk production, arched back, retracted abdomen, fever, increased respiratory rate, mild symptoms of indigestion, bloating, and ruminal hypomotility. With pericardial perforation, muffled cardiac auscultation and a positive jugular pulse may be accompanied by an edema of the pectoral region (EDDY, 2008; SCOTT, PENNY, MACRAE, 2011). Typical clinical symptoms such as tympanic sound, acute pain in the reticular region, and pain grunts may disappear between the $1^{\text {st }}$ and $2^{\text {nd }}$ day, making diagnosis more difficult. Restlessness and muscle contraction, followed by breathing pauses, may also be observed; these symptoms are more pronounced in the acute stages, as the signs of pain decrease with chronic processes (EDDY, 2008). Less severe or chronic cases may present nonspecific clinical symptoms (DIRKSEN, 1993; GUARD, 2006).

To diagnose reticuloperitonitis, reticular pain tests are used during the physical examination of the bovine (DIRKSEN, 1993); a positive response to the pain test is a grunt. The interpretation of the test results is necessarily cautious, as false-positive responses may result from the animal's temperament or the use of excessive force (DIRKSEN, 1993; FEITOSA, 2004).

An important complementary test to evaluate the presence of MFBs in cattle is transabdominal ferroscopy. The detection of MFB by ferroscopes is quick and easy but in the presence of reticular motility, it is not possible to distinguish between penetrated and non-penetrated MFBs. This is because the visual or audible signal emitted by the device will vary according to passive MFB movement by reticulum, hindered only when there are adhesions between the reticulum and adjacent structures (OLLHOFF; BIRGEL, 2012). Ferroscopy can be completed with a model specifically developed for bovine species and which is imported. The Hauptner ${ }^{\circledR}$ ferroscope is highly accurate for identifying metallic objects through audible and visual signals (HAUPTNER $^{\circledR}, 2008$ ).

For the convenience of being a national device, the GMS 120 Professional $\mathrm{BOSCH}^{\circledR}$ metal detector originally developed for use in civil construction has been used routinely in the field by buiatricians for cattle with suspected MFB intake. Thus, the objective of this study was to validate the GMS 120 Professional BOSCH${ }^{\circledR}$ metal detector for the detection of MFB in cattle.

\section{MATERIALS AND METHODS}

Initially 45 MFBs of various shape, size, and metallic composition (unknown metallic composition; UMC) and five MFBs of known composition (KMC - stainless steel, carbon steel, and aluminum) all may be accidentally ingested by cattle were selected. All of the materials were identified, weighed, and measured. To prevent irritation of the animal's mucosa, the tips of the MFBs were sealed with non-toxic aquarium silicone. The detection distance for each material was verified before insertion in the cow. With the aid of a ruler, the objects were tested separately on a flat and inert surface. First at a distance of 10 and $20 \mathrm{~cm}$ from the MD and then at the minimum detection distance. All measurements were made in triplicate and then averaged. The number of bars visualized in the MD was recorded, as well as the color change from green to yellow to red, indicating the presence of metal (according to the manufacturer's manual). The minimum detection distance (MinD) was established as the smallest detectable distance (in $\mathrm{cm}$ ) between the MD and the metallic object.

After obtaining these measurements, the MFBs were introduced into a fistulated adult cow 
belonging to the ruminant clinic herd of Pontifícia Universidade Católica do Paraná (PUCPR), with BCS (body condition score) 5 (obese). The ruminal fistula allowed the insertion and manual removal of objects in the ventral blind sac of the reticulum. The 50 MFBs were introduced individually, measuring the possibility of detection between the fifth and seventh intercostal space on the left side of the cow with the MD. Measurements were performed in triplicate with at least two minutes of measurement per object to allow a succession of reticular waves (i.e., contraction and relaxation).

From July 31 to October 31, 2017, an MD was used during the daily clinical routine of veterinarians of the Witmarsum Cooperative LTDA, in the municipality of Palmeira - PR and in the ruminant clinic of PUCPR, municipality of Fazenda Rio Grande - PR. At the same time, the cooperative's cattle care database was accessed from 2000 to 2017 , calculating the relative incidence of cattle detected with MFB. Beginning in 2013, the use of an MD was introduced.

The cattle were high and low yielding Holstein dairy cows. An MD was always used when there was a clinical suspicion of FB ingestion and compared to the physical examination for reticular pain. For convenience, a single reticular pain test, the withers pinch test, was administered. At the time of diagnosis and after inspection, appetite, milk production, fever (rectal temperature $>39.5^{\circ} \mathrm{C}$ ), and cardiac auscultation of the cattle was documented. For the evaluation of the cattle care database, descriptive statistics were used. Comparison of the casuistic before and after the use of MD was performed by the Qui ${ }^{2}$ test. Comparison of the weights, lengths, and distances of the yellow and red lights between the UMC and KMC groups was performed with the t-test, which assessed the homogeneity of variance by the Levene test, considering a difference for $\mathrm{p} \leq 0.05$ using Statgraphics Centurion 18 software.

\section{RESULTS}

Results of the measurements performed on flat and inert surfaces are presented in table 1, according to the average weight and length of the materials and the minimum detection distances. On the flat and inert surface and at a distance of $20 \mathrm{~cm}$, the MD did not detect any object; the light ring remained green, regardless of the material size and weight. At a distance of $10 \mathrm{~cm}$, two objects were detected, with the light ring in yellow. On the fistulated cow, the GMS 120 Professional $\mathrm{BOSCH}^{\circledR}$ metal detector did not detect any MFB, regardless of material size and weight.

Results of the MD use in the field with cows suspected of reticuloperitonitis are shown in table 2. In the field, the main complaints of the keepers of the 15 cows with suspected FB ingestion were characterized by decreased milk yield, weight loss, fever, apathy, and lack of appetite. The most observed clinical symptoms from MFB intake are listed in figure 1 and, of the 15 cows with suspected FB ingestion, all presented reduced milk yield, low feed intake, and positive withers pinch test for pain. Some cows also showed signs of muffled cardiac auscultation $(\mathrm{n}=12)$, fever $(\mathrm{n}=10)$, antalgic positions $(n=7)$ and chest edema $(n=3)$. Treatments performed on animals diagnosed with MFBs were exploratory rumenotomy $(\mathrm{n}=3)$, the use of a magnet $(\mathrm{n}=15)$, and systemic antibiotics $(\mathrm{n}=14)$. During one of the exploratory rumenotomy procedures, a magnet with an attached wire was removed. One cow died after diagnosis. The necropsy findings of

Table 1 - Minimum detection distance of the GMS 120 Professional BOSCH ${ }^{\circledR}$ metal detector for different ferrous materials of unknown composition (UMC; $n=45)$ and metals of known composition (KMC; $n=5)$, including nuts and bolts $(n=36)$, wires $(n=7)$, nails( $\mathrm{n}=7)$, all subject to ingestion by cattle.

\begin{tabular}{|c|c|c|c|c|}
\hline & Weight $(\mathrm{g})$ & Length $(\mathrm{cm})$ & D.D yellow light $(\mathrm{cm})$ & D.D red light $(\mathrm{cm})$ \\
\hline \multicolumn{5}{|c|}{ 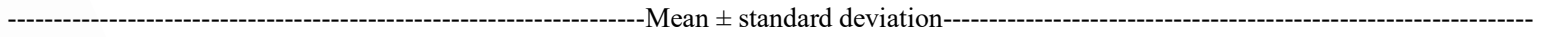 } \\
\hline KMC & $3.94 \pm 3.68$ & $2.86 \pm 1.86$ & $63 \pm 1.85$ & $4.58 \pm 1.71$ \\
\hline UMC & $5.80 \pm 6.23$ & $8.54 \pm 7.81$ & $5.68 \pm 1.19$ & $4.46 \pm 1.03$ \\
\hline Nuts/bolts & $4.60 \pm 4.40$ & $3.49 \pm 3.48$ & $6.25 \pm 1.80$ & $4.59 \pm 1.73$ \\
\hline Wires & $2.41 \pm 0.75$ & $2.43 \pm 1.13$ & $6.71 \pm 1.25$ & $4.50 \pm 0.95$ \\
\hline Nails & $3.37 \pm 3.03$ & $4.06 \pm 4.09$ & $5.09 \pm 2.33$ & $4.57 \pm 1.94$ \\
\hline P-value & 0.70 & 0.84 & 0.85 & 0.79 \\
\hline
\end{tabular}

Subtitle: D.D - detection distance. 
Table 2 - Comparison between the reticulum pain tests and the detection of metallic foreign body by the GMS 120 Professional $\mathrm{BOSCH}^{\circledR}$ metal detector in cattle $(\mathrm{n}=15)$ suspected of traumatic reticuloperitonitis.

\begin{tabular}{lcccc}
\hline Pain test & Visual sign & Visual sign & Acoustic sign & Yellow light \\
\hline Positive & 4 stripes & 5 stripes & & \\
$15(100 \%)$ & $3(20 \%)$ & $5(33.3 \%)$ & $8(53.3 \%)$ & $1(6.6 \%)$ \\
\hline
\end{tabular}

this cow were reticulopericarditis, adhesions between the reticulum, diaphragm, and pericardial sac, fibrin cap, and the presence of an MFB in the heart. Field services performed and the relative frequencies of MFB detection between 2000 and 2017 are shown in table 3, with a clear increase in the diagnosis of MFB presence after the introduction of MD usage.

\section{DISCUSSION}

The impossibility of detection at a distance of $20 \mathrm{~cm}$ is justifiable, as the Bosch GMS - 120 metal detector has a maximum detection depth of $12 \mathrm{~cm}$ (MANUAL BOSCH ${ }^{\circledR}$, 2016). However, this maximum detectable distance was never reached; it remained at least $2 \mathrm{~cm}$ shorter. Even when measuring MFBs on the bench, the average detection distance with acoustic signal was below $5 \mathrm{~cm}$, which is approximately the wall thickness of the costal grid, with the abdominal wall having on average 2 - $4 \mathrm{~cm}$ thickness (SCOTT, 2012) and may increase considerably from fat deposition in the subcutaneous tissue or, in the case of reticuloperitonitis, with the accumulation of fluid or pus between the peritoneum and the reticular wall.

The fistulated cow assisted in the verification of MD detection capacity, since the exact nature of the MFB was known, as well as its intraabdominal location in the ventral sac of the reticulum. As the fistulated cow had a BCS of 5 (obese), the distance from the abdominal wall to the reticulum was greater than the device's detectable distance. This justifies the absence of positive detection signals. Therefore, the Bosch MD would be less efficient at detecting MFBs than the Hauptner model. Additionally, the visual signal of the Bosch MD may be more difficult to observe and the sound produced could scare the cattle, which is not the case with the

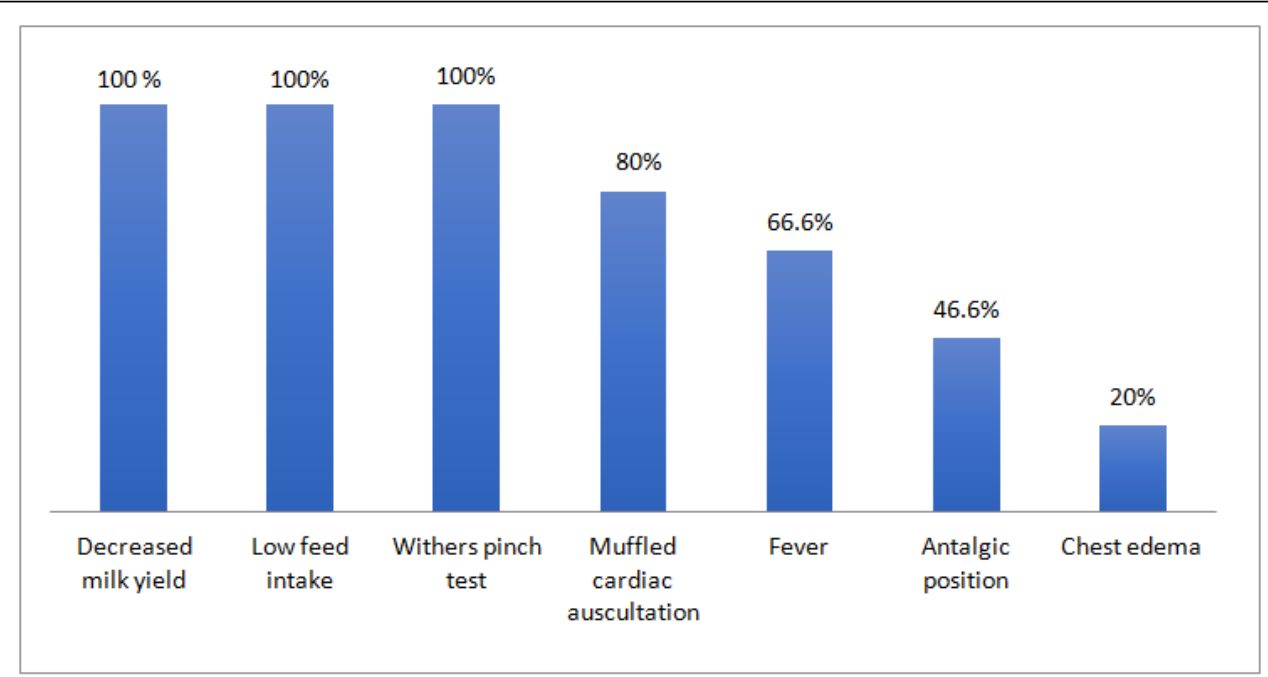

Figure 1 - Relative frequency of clinical signs observed in dairy cows $(n=15)$ with suspected traumatic reticuloperitonitis. 
Table 3 - The number of cases treated by the Witmarsum Cooperative Ltd. and the relative frequency of detection of metallic foreign bodies, from 2013, with the use of a metal detector.

\begin{tabular}{|c|c|c|c|c|}
\hline Year & Total cattle examined & Cattle with ingestion of MFB & $\%$ of cattle with MFB & Detection percentage \\
\hline 2000 & 7461 & 14 & 0.19 & \multirow{13}{*}{$0.29^{\mathrm{a}}$} \\
\hline 2001 & 6896 & 8 & 0.17 & \\
\hline 2002 & 6304 & 7 & 0.11 & \\
\hline 2003 & 6512 & 12 & 0.18 & \\
\hline 2004 & 6224 & 5 & 0.08 & \\
\hline 2005 & 6372 & 14 & 0.22 & \\
\hline 2006 & 6367 & 18 & 0.28 & \\
\hline 2007 & 7079 & 16 & 0.23 & \\
\hline 2008 & 7302 & 24 & 0.33 & \\
\hline 2009 & 7223 & 28 & 0.39 & \\
\hline 2010 & 7151 & 19 & 0.27 & \\
\hline 2011 & 7543 & 64 & 0.85 & \\
\hline 2012 & 7716 & 32 & 0.41 & \\
\hline 2013 & 6825 & 48 & 0.70 & \multirow{5}{*}{$1.35^{\mathrm{b}}$} \\
\hline 2014 & 6637 & 73 & 1.10 & \\
\hline 2015 & 6128 & 92 & 1.50 & \\
\hline 2016 & 6438 & 96 & 1.49 & \\
\hline 2017 & 5837 & 122 & 2.09 & \\
\hline Total 2000 a 2017 & 122015 & 692 & 0.57 & \\
\hline
\end{tabular}

$\mathrm{a}, \mathrm{b}$ - Different letters in the same column indicate statistical difference by the chi-square test $(\mathrm{P} \leq 0.05)$.

specific model developed by Hauptner (OLLHOFF \& BIRGEL JR., 2012). The Bosch GMS - 120 MD also places the operator, especially during use in more frightened or nervous cattle, at risk of being kicked on the upper back and head, because to observe the light signal during the examination, the examiner must lower their trunk and the head. The advantages of the device are its low weight and cost, compared to the imported model.

The clinical symptoms presented by the 15 cows diagnosed with MFB intake are indicative of traumatic reticuloperitonitis (EDDY, 2008). The use of the other classically described reticulum pain tests (DIRKSEN, 1993) could have increased the diagnostic accuracy of abdominal pain, as only the withers pinch test was used here. Major clinical symptoms, such as reduced milk production and low feed intake, as well as the high risk of death or early discarding, results in large economic losses for the farmer (EDDY, 2008). Decreased feed intake and consequent weight loss in cows is also prevalent in African studies (BWATOTA et al. 2018). A skinny cow is indispensable to use the Bosch MD as it reduces the distance between it and a possible MFB.

The use of an orally applied magnet is a conservative and prophylactic treatment. The MFB are attracted and attached to the magnet, limiting their migration into the animal's organism, which may or may not be removed by rumenotomy (GUARD, 2006; CHANIE; TESFAYE, 2012). Once inside the reticulum, magnets can be confused for MFBs by the MD. For differentiation a compass is used, whose north will be attracted to the magnet.

Following the acquisition of the GMS 120 Professional $\mathrm{BOSCH}^{\circledR}$ metal detector by the Witmarsum LTDA Cooperative in 2013, the number of MFB intake diagnoses increased. It is noteworthy that the cooperative veterinary team did not change during these years; only in the last year did a new collaborator enter. This, on the one hand, demonstrated the effectiveness of using the detector as a diagnostic aid, but it may also have occurred due to the increase in metallic materials, whether pointed or not, left on the farm premises in a neglected way. The possibility of using the GSM metal detector in skinny cows with suspected reticuloperitonitis should be evaluated to assist the decision to place a magnet. As the insertion of the magnet was done in all the cases diagnosed by the field veterinarians, there would be no need to use the detector. Perhaps the increase in the number of cases occurred, due to the simple availability of 
the detector, easier to find and cheaper for the farmer. In these cases, a greater awareness of the problem is created, both for veterinarians and farmers, demanding a greater amount of veterinary services in this area. The Bosch GSM 120 metal detector could be upgraded by the company for its targeted use as a field veterinary device.

\section{CONCLUSION}

The Bosch GMS-120 metal detector used for the detection of MFBs in cattle detects only MFBs in cattle in specific situations, where the MFB is close to the machine. It is not recommended for larger, due to breed or body score, animals, where the distance between the MD and the MFB is likely to be greater than $10 \mathrm{~cm}$. In skinnier cows, where the MFBs are likely to be less than $10 \mathrm{~cm}$ from the detector, detection can be performed. Failure of the device to detect an MFB does not exclude an MFB intake. The device should be considered as a diagnostic aid in specific situations.

\section{ACKNOWLEDGMENTS}

The authors thank the Witmarsum Cooperative; Araucaria Foundation and dairy cattle producers.

\section{BIOETHICS AND BIOSSECURITY COMMITTEE APPROVAL}

This study was approved by the PUCPR Animal Research Ethics Committee (CEUA), under number 01122.

\section{DECLARATION OF CONFLICT OF INTERESTS}

The authors declare no conflict of interest. The founding sponsors had no role in the design of the study; in the collection, analyses, or interpretation of data; in the writing of the manuscript, and in the decision to publish the results.

\section{AUTHORS' CONTRIBUTIONS}

All authors contributed equally for the conception and writing of the manuscript. All authors critically revised the manuscript and approved of the final version.

\section{REFERENCES}

BOSCH. Bosch GMS 120 Professional: Manual do utilizador. Germany, 2016. p.23-27.
BWATOTA, S. F. et al. Occurrences of indigestible foreign bodies in cattle slaughtered at Morogoro municipal slaughterhouse, Tanzania. Journal of Veterinary Medicine, v.2018, p.1-6, 2018. Accessed: May, 03, 2019. doi: 10.1155/2018/4818203.

CHANIE, M.; TESFAYE, D. Clinico-pathological findings of metallic and non-metallic foreign bodies in dairy cattle: A review. Academic Journal of Animal Diseases, v.1 (3), p.13-20, 2012. Accessed: Feb. 19, 2019. doi: 10.5829/idosi. ajad.2012.1.3.7524

DIRKSEN, G. Sistema Digestivo. In: DIRKSEN, G.; GRÜNDER, H.; STÖBER M. Rosenberger Exame Clínico dos Bovinos. 3. ed. Rio de Janeiro: Guanabara Koogan S.A, 1993. Cap.7, p.166-228

DIRKSEN, G.; et al. Innere Medizin und Chirurgie des Rindes. 4 ED. Berlin, Viena: Blackwell, 2002. 1325p.

EDDY, R. G. Doenças do Sistema Digestório. In: ANDREWS, A. H.; BLOWEY, R. W.; BOYD, H.; EDDY, R. G. Medicina Bovina: Doenças e Criação de Bovinos. 2. ED. São Paulo: Roca, 2008. Cap.48, p.725-759.

FEITOSA, F. L. F. Semiologia do Sistema Digestório de Ruminantes. In: FEITOSA, F. L. F. Semiologia Veterinária: a Arte do Diagnóstico. São Paulo: Roca, 2004. Cap.5, p.108-138.

GARCIA, M. et al. Descrição das doenças. Manual de Semiologia e Clínica dos Ruminantes. São Paulo: Varela, 1996. Parte II, p.153-218.

GUARD, C. Enfermidades do Trato Alimentar: Retículo Peritonite-Traumática. In: SMITH, B. P. Medicina Interna de Grandes Animais. 3. ed. Barueri: Manole, 2006. Cap.30, p.593-789.

HAUPTNER. Animal identification Stock Breeding equipment Veterinary instruments. catálogo. Solingen, 2008. 8p.

SEREN, E. Enfermedades por Procesos Inflamatorios y Disfuniones Motoras Primitivas. Enfermedades de los Estomagos de los Bovidos. Zaragoza: Acribia, 1975. Cap.2, p.143-222.

SCOTT, P. R. Abdominal ultrasonography as an adjunct to clinical examination 2. Cattle. Farm Animal Practice. v.34, p.66-72, 2012. Accessed: Apr. 6, 2019. doi: 10.1136/inp.e744.

SCOTT, P. et al. Cattle Medicine. London: Manson Publishing Ltd, 2011. p.59-114.

STÖBER, M. Identificação, Anamnese, Regras Básicas da Técnica de Exame Clínico Geral. In: DIRKSEN, G.; GRÜNDER, H.; STÖBER, M. Rosenberger Exame Clínico dos Bovinos. 3. ed. Rio de Janeiro: Guanabara Koogan S.A, 1993. Cap.2, p.44-80.

OLLHOFF, R. D.; BIRGEL JUNIOR, E. H. Detecção de corpos estranhos metálicos por meio de ferroscopia em rebanho bovino de leite de alta produção. Arquivos do Instituto Biológico. v.79, n.3, p.415-417, 2012. Accessed: Feb. 22, 2019. doi: 10.1590/S180816572012000300013 